\title{
ANALISIS KADAR ALBUMIN IKAN SIDAT (Anguilla marmorata dan Anguilla bicolor) DAN UJI AKTIVITAS PENYEMBUHAN LUKA TERBUKA PADA KELINCI (Oryctolagus cuniculus)
}

\section{ANALYSIS OF ALBUMIN LEVELS OF THE EELS (Anguilla marmorata and Anguilla bicolor) AND EXAMINATION OF ITS OPEN WOUND HEALING ACTIVITY ON RABBIT (Oryctolagus cuniculus)}

\author{
Ariza Abu Bakar Putri ${ }^{1 *}$, Yuliet ${ }^{1}$, Jamaluddin ${ }^{1}$ \\ ${ }^{1}$ Jurusan Farmasi, Fakultas MIPA, Universitas Tadulako, Palu, Indonesia
}

Received 4 Agustus 2016, Accepted 14 September 2016

\begin{abstract}
ABSTRAK
Ikan sidat merupakan salah satu ikan yang mengandung albumin. Albumin bermanfaat dalam pembentukan jaringan tubuh yang baru pada masa pertumbuhan dan dapat mempercepat penyembuhan jaringan tubuh. Penelitian ini bertujuan untuk mengetahui kadar albumin pada ikan sidat (Anguilla marmorata dan Anguilla bicolor) serta efek albumin terhadap penyembuhan luka terbuka. Kadar albumin ikan sidat ditentukan dengan menggunakan metode Bromocresol green dan dilakukan secara triplo. Hasil penelitian menunjukkan bahwa rerata kadar albumin spesies Anguilla marmorata adalah 13,269 mg/100 g serta rerata kadar albumin untuk spesies Anguilla bicolor adalah 8,998 mg/100 g. Kadar albumin ikan sidat yang tertinggi dilanjutkan ke uji penyembuhan luka terbuka dengan menggunakan 5 ekor kelinci. Tiap kelinci diberi 5 perlakuan/luka terbuka dengan masing-masing konsentrasi yaitu kontrol positif yang mengandung povidone iodine, kontrol negatif (basis salep), konsentrasi ekstrak albumin 5\%, 10\% dan 15\%. Luka terbuka pada kelinci diamati pada hari ke-1, $3,5,7,10,12$, dan 14. Analisis data pengujian kadar albumin menggunakan uji IndependenT test, dan analisis data persentase penyembuhan luka terbuka menggunakan uji Two Way ANOVA. Hasil analisis Independen T test terhadap kadar albumin menunjukkan adanya perbedaan signifikan terhadap kadar albumin pada ikan sidat spesies Anguilla marmorata dan Anguilla bicolor, dengan kadar albumin tinggi terdapat pada ikan sidat spesies Anguilla marmorata. Konsentrasi efektif albumin untuk penyembuhan luka yaitu konsentrasi 5\% dengan persentase penyembuhan luka mencapai $100 \%$.
\end{abstract}

Kata Kunci :Albumin, Anguilla marmorata, Anguilla bicolor, Bromocresol green, Oryctolagus cuniculus.

\begin{abstract}
Eel is one kind of fish which contain albumin. Albumin is useful in the formation of new body tissue during growth and can accelerate the healing of body tissue. This study aimed to determine levels of albumin in the eels (Anguilla marmorata and Anguilla bicolor) as well as its effect of open wound healing tested at various concentrations. The albumin levels were determined using Bromocresol green method with three times repetition. The results showed that average albumin levels of Anguilla marmorata was 13,269 mg/100 g and Anguilla bicolor was $8,998 \mathrm{mg} / 100 \mathrm{~g}$. Eel extract with the highest level of albumin was continued to pharmacological tests using 5 rabbits which had been open-wounded in 5 areas. Each rabbit was then given 5 treatments. The first two rabbits got positive control containing povidone iodine and negative control (ointment base), while the other three got albumin extract successively at concentration of 5\%,10\% and $15 \%$. The wounds were observed on days $1,3,5,7,10,12$, and 14. The data analysis for albumin levels was done using Independent $T$ test and for open wound healing percentage using One Way ANOVA. The analysis results showed a significant difference of albumin levels between Anguilla marmorata and Anguilla bicolor and it found that the highest level of albumin was in Anguilla marmorata species. The effective extract concentration of albumin in wound healing was at concentration of $5 \%$ with wound healing percentage of up to $100 \%$.
\end{abstract}

Keywords : Albumin, Anguilla marmorata, Anguilla bicolor, Bromocresol green, Oryctolagus cuniculus.

*Coresponding author : Ariza Abu Bakar Putri, Arizaputry_36@yahoo.com 


\section{PENDAHULUAN}

Ikan sidat (Anguilla sp.) merupakan jenis ikan yang laku di pasar internasional (Jepang, Hongkong, Jerman, Italia, dan beberapa negara lainnya). Dengan demikian ikan ini memiliki potensi sebagai komoditas ekspor (Affandi, 2005).

Di Indonesia sumber daya ikan sidat belum banyak dimanfaatkan. Hal ini terlihat dari tingkat pemanfaatan ikan sidat secara lokal (dalam negeri) masih sangat rendah, padahal jumlah ikan ini baik dalam ukuran benih maupun ukuran konsumsi cukup melimpah. Salah satu penyebabnya adalah ikan ini belum banyak dikenal, sehingga kebanyakan penduduk Indonesia belum familiar untuk mengkonsumsi ikan sidat.

Sulawesi Tengah, khususnya wilayah Poso memiliki potensi ikan sidat (sogili) yang cukup tinggi karena didukung oleh Teluk Tomini yang cukup dalam serta keberadaan perairan darat yang luas yaitu Danau Poso (McKinnon, 2006). Ada 5 (lima) jenissidat yang terdapat di DanauPosoyaituAnguilla marmorata (Q.) Gaimard, Anguilla celebensis, Anguilla interioris, Anguilla bicolor pacific, dan Anguilla borneoensis (Anonim a, 2010). Hasil tangkapan ikan di Danau Poso didominasi oleh jenis ikan sidat yaitu sekitar $40 \%$ dari total tangkapan sebesar 75,54 ton/tahun (Anonim, 2005).

Lendir sidat juga dimanfaatkan untuk pengobatan tradisional seperti pengobatan pada luka (Roy, 2013). Sidat merupakan ikan konsumsi yang sangat digemari dibanyak negara khususnya Jepang, Cina, Jerman, dan Perancis karena selain memiliki rasa unik juga sangat kaya akan vitamin A, B1, B2, B6, C, D, protein albumin, DHA (Docosahexaenoic acid) dan EPA (Eicosapentaenoic acid) lebih dikenal dengan omega-3, serta beberapa mineral lainnya (Rovara, 2010).

Albumin berfungsi untuk mengatur tekanan osmotik dalam darah dan juga sebagai sarana pengangkut atau transportasi. Albumin bermanfaat dalam pembentukan jaringan tubuh yang baru pada masa pertumbuhan dan dapat mempercepat penyembuhan jaringan tubuh (Suprayitno, 2009; Poedjiadi, 2006). Pengujian secara ilmiah yang dilakukan oleh Sinambela (2012), menyatakan bahwa ikan gabus yang mengandung albumin memiliki aktivitas dan efektivitas terhadap penyembuhan luka sayat dimana sediaan salep minyak ikan gabus pada konsentrasi $10 \%$ dapat memberikan hasil terbaik terhadap penutupan luka sayat dengan luka menutup hari ke-8.

Luka merupakan hilang atau rusaknya sebagian jaringan tubuh (Syamshu hidayat, 1998). Secara alamiah jaringan tubuh yang menderita luka akan berusaha memperbaiki diri. Kesembuhan ini dikenal sebagai kesembuhan alami. Mengingat fungsi kulit yang sangat penting, yaitu untuk melindungi tubuh dari trauma maupun sebagai penahan terhadap kuman, virus, dan jamur maka sebaiknya jika terjadi luka pada kulit harus segera diobati (Price and Wilson, 1982).

Berdasarkan uraian di atas, maka penting dilakukan analisis kadar albumin pada ikan sidat terutama spesies Anguilla bicolor dan Anguilla marmorata (Q.) Gaimard yang terdapat di perairan Danau Poso. Selain itu juga untuk menguji kemampuan ekstrak albumin yang diperoleh dari salah satu spesies ikan sidat Anguilla bicolor dan Anguilla marmorata (Q.) Gaimard terhadap penyembuhan luka terbuka pada hewan uji kelinci (Oryctolagus cuniculus).

\section{BAHAN DAN METODE Bahan}

Bahan utama yang digunakan adalah ikan sidat spesies Anguilla bicolor dan Anguilla marmorata(Q.) Gaimard yang diperoleh dari Danau Poso.

Bahan untuk uji kadar albumin menggunakan metode bromocresol green yaitu reagen bromocresol green, reagen standar albumin, dan reagen control.

Bahan untuk uji aktivitas penyembuhan luka terbuka yaitu ketamin $10 \mathrm{~mL}$, kapas, alkohol $70 \%$, betadine salep, dan aqua pro injection.

\section{Hewan Uji}

Hewan uji yang digunakan dalam penelitian ini yaitu hewan kelinci dengan umur 4-10 bulan dan dengan berat badan 1,5-2,5 kg sebanyak 5 ekor.

\section{Metode Penelitian}

Penelitian ini merupakan penelitian eksperimen laboratorium dimana dengan menggunakan metode bromocresol green dan dengan alat photometer. Serta uji aktivitas albumin ikan sidat terhadap penyembuhan luka terbuka pada hewan uji kelinci. 


\section{Waktu dan Tempat Penelitian}

Penelitian ini dilaksanakan pada bulan Mei-Juli 2015. Bertempat di Laboratorium Kesehatan, Palu, Sulawesi Tengah, Laboratorium Farmakognosi - Fitokimia, Laboratorium Farmakologi - Biofarmasi FMIPA, UniversitasTadulako, Palu, Sulawesi Tengah.

\section{Tahap Persiapan Bahan Uji}

Sampel ikan Sidat (Anguilla marmorata (Q.) Gaimard) dan (Anguilla bicolor) diperoleh dari Danau Poso.

\section{Tahap Preparasi Sampel}

Ikan sidat dibersihkan (dihilangkan sisik, insang, dan isi perut), kemudian dicuci sampai tidak ada lagi darah dan lendir, dipotong menjadi potongan-potongan kecil dan tulang dihilangkan. Kemudian dihaluskan menggunakan blender dan ditambahkan pelarut dengan perbandingan $1: 1 \mathrm{v} / \mathrm{b}(100 \mathrm{~mL}$ pelarut air : $100 \mathrm{~g}$ ikan) untuk ekstrak kasar.

\section{Tahap Ekstraksi}

Ekstraksi albuminnya yaitu dengan menggunakan pelarut $\mathrm{HCl} 0,1 \mathrm{M}$ dengan pemanasan pada suhu $50-60 \square \mathrm{C}$ selama 10 menit. Kemudian disaring untuk memisahkan cairan dan residu, lalu cairan ditambah dengan $200 \mathrm{~mL}$ heksana, dan dikocok selama 30 menit. Sehingga terbentuk dua fase, fase minyak dan fase air (cairan ekstrak). Fase minyak dipisahkan dan ditampung dengan wadah penampung. Cairan ekstrak yang diperoleh (fase air) siap dianalisis.

Tahap Uji Kualitatif Protein Albumin (Yazid, dkk., 2006 dan Hairima, dkk, 2014)

Ekstrak ikan sidat (Anguilla marmorata dan Anguilla bicolor) diuji secara kualitatif menggunakan uji biuret, uji xanthoprotein, dan uji secara visual terhadap adanya protein albumin.

\section{Tahap Uji Kuantitatif Ekstrak Albumin Ikan Sidat}

Ekstrak albumin ikan sidat (Anguilla marmorata dan Anguilla bicolor) diuji secara kuantitatif menggunakan metode Bromocresol green dan menggunakan alat photometer untukmengetahui kadar tertinggi diantara kedua spesies tersebut.

\section{Pengujian Efek Sediaan Ekstrak Albumin Terhadap Penyembuhan Luka Terbuka Kelinci}

Hewan uji yang digunakan berjumlah 5 ekor, kemudian dibagi menjadi 5 kelompok uji. Perlakuan dilakukan selama 7 hari.
Kelinci I : diberi betadine salep sebagai kontrol positif

Kelinci II : diberi basis salep (vaselin kuning dan adeps lanae) sebagai kontrol negatif

Kelinci III : diberi ekstrak albumin ikan sidat dengan konsentrasi $5 \%$

Kelinci IV : diberi ekstrak albumin ikan sidat dengan konsentrasi $10 \%$

Kelinci V : diberi ekstrak albumin ikan sidat dengan konsentrasi $15 \%$

\section{Pengukuran Persentase Penyembuhan Luka Sayat}

Kesembuhan luka dinilai dengan cara mengukur rata-rata panjang luka setiap harinya dimulai pada hari pertama pembuatan luka sampai pada hari ke-14, dengan menghitung persentase penyembuhan luka.

\section{Untuk}

persentasepenyembuhanlukaterbukadihitungde nganrumus:

$\mathrm{P} \%=\frac{\mathrm{do}-\mathrm{dx}}{\mathrm{do}} \times 100 \%$

$\mathrm{P} \%$ untukpersentasepenyembuhanluka, $d_{0}$ untukpanjang lukaawaldan $d_{x}$ untukpanjang lukapadahariterakhir.

\section{HASIL DAN PEMBAHASAN}

Hasil Analisis Secara Kualitatif

Ekstrak ikan sidat (Anguilla bicolor dan Anguilla marmorata) positif mengandung protein albumin dengan menggunakan 3 metode uji yaitu secara biuret, xanthoprotein, dan secara visual.

Tabel 1. Hasil Analisis Kadar Albumin Secara Kualitatif

\begin{tabular}{|c|c|c|c|c|}
\hline \multirow{2}{*}{ No } & \multirow{2}{*}{ Zat Uji } & \multicolumn{3}{|c|}{ Metode Uji } \\
\hline & & Biuret & Xanthoprotein & Visual \\
\hline 1. & Albumin & + & + & + \\
\hline 2. & $\begin{array}{c}\text { Ekstrak } \\
\text { Anguilla } \\
\text { marmorata } \\
2 \%\end{array}$ & + & + & + \\
\hline
\end{tabular}




$\begin{gathered}\text { Ekstrak } \\ \text { Anguilla } \\ \text { bicolor } 2 \%\end{gathered}++\quad+\quad+\quad+$

Uji biuret digunakan untuk uji protein, karena uji ini dapat mendeteksi adanya ikatan peptide yang diperoleh hasil reaksi berupa warna ungu pada larutan yang menunjukkan adanya protein. Berdasarkan Tabel 1 uji biuret terlihat bahwa semua sampel terjadi perubahan warna menjadi ungu. Hal ini terjadi karena ion $\mathrm{Cu}^{2+}$ (dari pereaksi Biuret) dalam suasana basa bereaksi dengan polipeptida atau ikatan-ikatan peptida yang menyusun protein membentuk senyawa kompleks berwarna ungu (violet) (Yazid \& Nursanti, 2006).

Uji xanthoprotein membuktikan adanya asam amino torisin, triptofan, atau fenilalanin yang terdapat dalam protein. Jika protein yang mengandung cincin benzena (tirosin, triptofan, dan fenilalanin) ditambahkan asam nitrat pekat, maka akan terbentuk endapan putih yang dapat berubah menjadi kuning sewaktu dipanaskan. Senyawa nitro yang terbentuk dalam suasana basa akan terionisasi dan warnanya berubah menjadi jingga (Yazid \& Nursanti, 2006). Pengujian kualitatif yang terakhir yaitu pengujian secara visual. Hasil yang didapat positif mengandung ekstrak albumin.

\section{Hasil Uji Kuantitatif Ekstrak Albumin Ikan Sidat}

Ekstrak albumin ikan sidat diuji secara kuantitatif untuk mengetahui spesies mana yang kadar albuminnya lebih tinggi.

\begin{tabular}{|c|c|c|c|c|c|}
\hline ab & $\begin{array}{l}\text { D } \\
\text { ek } \\
\text { kt }\end{array}$ & $\begin{array}{l}\text { a an } \\
\text { rak } \\
\text { ntitati }\end{array}$ & $\begin{array}{l}\text { lisis } \\
\text { ikan }\end{array}$ & $\begin{array}{l}\text { adar } \\
\text { sidat }\end{array}$ & $\begin{array}{r}\text { lbumin } \\
\text { secara }\end{array}$ \\
\hline \multirow{2}{*}{ No } & \multirow{2}{*}{$\begin{array}{c}\text { Jenis } \\
\text { Sampel }\end{array}$} & \multicolumn{3}{|c|}{ Kadar albumin $(\mathrm{mg} / 100 \mathrm{~g})$} & \multirow{2}{*}{$\begin{array}{c}\text { Rata- } \\
\text { rata } \pm \\
\text { SD }\end{array}$} \\
\hline & & I & II & III & \\
\hline 1 & $\begin{array}{l}\text { Anguilla } \\
\text { bicolor }\end{array}$ & 9,24 & 8,998 & 8,756 & $\begin{array}{c}8,998 \pm \\
0,242\end{array}$ \\
\hline 2 & $\begin{array}{c}\text { Anguilla } \\
\text { marmorata }\end{array}$ & 13,552 & 13,574 & 12,683 & $\begin{array}{c}13,269 \\
\pm 0,508^{*}\end{array}$ \\
\hline
\end{tabular}

Ket : * menunjukkan adanya perbedaan yang signifikan

Berdasarkan hasil yang didapat, kadar rata-rata albumin yang diperoleh untuk spesies Anguilla marmorata yaitu $0,508 \mathrm{mg} / 100 \mathrm{~g}$ dan kadar rata-rata albumin untuk spesies Anguilla bicolor yaitu 0,242 mg/100 g. Berdasarkan uji statistik independen $T$ test menyatakan adanya perbedaan yang signifikan antara kadar albumin pada ikan sidat spesies Anguilla marmorata dan Anguilla bicolor.Diantara keduanya, spesies Anguilla marmorata yang memiliki kadar yang lebih tinggi. Maka ekstrak albumin ikan sidat Anguilla marmorata dilanjutkan ke pengujian efek sediaan ekstrak albumin terhadap penyembuhan luka terbuka pada kelinci.

\section{Hasil Pengujian Efek Sediaan Ekstrak Albumin Terhadap Penyembuhan Luka Terbuka Kelinci}

Persentase penutupan luka tiap harinya sampai hari ke - 14 dapat dilihat pada Tabel 3

Tabel 3. Persentase Penutupan Luka

\begin{tabular}{|c|c|c|c|c|c|c|}
\hline \multirow{2}{*}{$\begin{array}{l}\text { Ralispol } \\
\text { Pelitive }\end{array}$} & \multicolumn{6}{|c|}{ 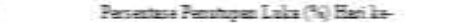 } \\
\hline & 3 & 5 & 7 & II & 27 & 14 \\
\hline Ental Wegef & 853 & 1454 & $n m$ & 55,48 & 3,5 & $\mathrm{n} 3 \mathrm{~s}$ \\
\hline Sratul Prsacf & 13,53 & 2290 & 43,13 & 69,12 & 8753 & 99,26 \\
\hline Sraventrei IP, & 15,26 & 25,45 & 45,05 & 2226 & 90,51 & $1 \mathrm{w}$ \\
\hline S-madrai $10 \%$ & 9,12 & 19,89 & 33,82 & 61,86 & $8: 99$ & 93,5 \\
\hline Soaseata: 15\%: & 8.55 & 1950 & 33,7 & 61,69 & 8366 & IE, I \\
\hline
\end{tabular}

Berdasarkan hasil persentase penyembuhan luka pada hewan uji dinyatakan sembuh dengan ditandai perubahan panjang luka yang semakin mengecil atau persentase penyembuhan luka yang semakin besar.

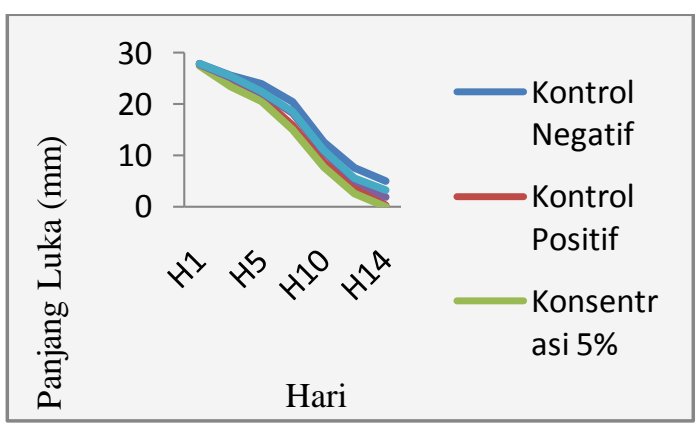

Gambar 1. Grafik penyembuhan luka setiap hari

Fase air ekstrak ikan sidat Anguilla marmorata dibuat dengan variasi konsentrasi $5 \%, 10 \%$, dan $15 \%$ yang ditambahkan dengan basis salep adeps lanae dan vaselin kuning. Pemilihan variasi konsentrasi dan basis salep yang digunakan yaitu bedasarkan penelitian sebelumnya oleh Hairima, dkk, 2014, untuk variasi konsentrasi dimana ekstrak $10 \%$ pada ikan gabus lebih cepat penyembuhan lukanya. Basis yang digunakan termasuk jenis basis 
salep yang mudah larut dalam air, sehingga basis tersebut dapat bercampur dengan fase air ektrak ikan sidat Anguilla marmorata. Konsentrasi basis yang digunakan yaitu 5\% adeps lanae dan vaselin kuning hingga $100 \mathrm{~g}$. Keuntungan salep yaitu sebagai bahan pembawa substansi obat untuk pengobatan kulit, sebagai bahan pelumas kulit, dan sebagai pelindung kulit yaitu mencegah kontak permukaan kulit dengan larutan berair dan rangsang kulit (Anief, 2007).

Hasil analisis statistik menunjukkan bahwa kelompok kontrol positif yang mengandung povidone iodine dengan kelompok yang diberi basis salep dengan konsentrasi 5\% memberikan perbedaan yang tidak signifikan namun berbeda signifikan dengan kelompok kontrol negatif yang dibuat dengan basis salep tanpa ekstrak albumin dan ekstrak albumin dengan konsentrasi $10 \%$ dan 15\%. Ekstrak albumin dengan konsentrasi $10 \%$ dan $15 \%$ yang diberi basis salep memberikan perbedaan yang tidak signifikan dengan kelompok kontrol negatif yang diberi basis salep.

Ekstrak albumin dengan konsentrasi 10\% dan $15 \%$ memiliki efek penyembuhan yang lebih kecil daripada ekstrak albumin pada konsentrasi 5\%. Hal ini karena berat molekul dari albumin ikan sidat sangat tinggi sehingga semakin tinggi konsentrasi maka semakin sulit untuk berdifusi, dimana berat molekul ikan sidat IgM adalah 790 kDa (Aida, dkk., 2003). Senyawa dengan bobot molekul lebih rendah akan berdifusi lebih cepat daripada dengan senyawa dengan bobot molekul tinggi, paling tidak karena membentuk ikatan dengan konstituen membran (Aiache, 1982). Hasil statistik juga menyatakan adanya perbedaan yang signifikan persentase penutupan luka terhadap waktu pengamatan dimana semakin lama waktu pengamatan persentase penyembuhan luka semakin besar.

Mekanisme albumin pada penyembuhan luka dimana pada tahapan proses inflamasi albumin berperan dalam mengatur tekanan osmotik di dalam darah dan merupakan hampir $50 \%$ protein plasma (Murray, dkk., 2009). Pada saat terjadi luka pada suatu jaringan kulit, kulit akan menunjukkan tanda inflamasi atau peradangan dimana benda asing dari luar tubuh dapat masuk melalui luka yang terbuka seperti luka sayat, masuknya benda asing ini memicu gangguan tekanan hidrostatik dimana cairan intrasel akan masuk kedalam sel karena adanya perbedaan atau ketidakseimbangan konsentrasi didalam dan diluar sel melalui jalur osmotik sehingga menyebabkan sel mengalami edema atau pembengkakan. Kondisi ini memerlukan nutrisi albumin yang dapat menjaga tekanan osmotik didalam dan diluar sel, sehingga edema yang terjadi tidak bertambah parah (Mansjoer, 2000; Suriadi, 2007).

Pada fase maturasi, albumin berperan sebagai bahan dasar melalui perombakan katabolik tubuh untuk membentuk kolagen. Kolagen berkembang cepat menjadi faktor utama pembentuk matrik. Serabut kolagen pada permulaan terdistribusi acak membentuk persilangan dan beragregasi menjadi bundelbundel fibril yang perlahan menyebabkan penyembuhan jaringan dan meningkatkan kekakuan dan kekuatan ketegangan. Pengembalian kekuatan tegangan berjalan perlahan karena deposisi jaringan kolagen terus menerus, remodeling serabut kolagen membentuk bundel-bundel kolagen lebih besar dan perubahan dari cross linking inter molekuler. Remodeling kolagen selama pembentukan jaringan parut tergantung pada proses sintesis dan katabolisme kolagen yang berkesinambungan (Mercandetti, 2014).

Mekanisme kerja povidone iodine dimulai setelah kontak langsung dengan jaringan maka elemen iodine akan dilepaskan secara perlahan-lahan dengan aktivitas menghambat metabolism enzim bakteri sehingga mengganggu multiplikasi bakteri yang mengakibatkan bakteri menjadi lemah. Iodine dalam jumlah yang kecil diserap masuk ke dalam aliran darah, sehingga menyebabkan efek sistemik dengan akibat shock anoksia jaringan. Povidone iodine yang biasa digunakan dalam perawatan luka hanya $10 \%$. Hasil suatu penelitian menyatakan bahwa semakin tinggi konsentrasi iodine yang digunakan semakin mempercepat penyembuhan luka (Gunawan, 2007).

\section{DAFTAR PUSTAKA}

Affandi, R. (2005). Strategi Pemanfaatan Sumberdaya Ikan Sidat Anguilla spp di Indonesia, Departemen Manajemen Sumberdaya Perairan, FPIK-IPB. 
Aiache, J.M. (1982). Farmasetika 2 Biofarmasi, Edisi Kedua, Penerjemah : Widji Soeratri, Penerbit Airlangga University Press, Surabaya.

Aida, K., Tsukamoto, K., \& Yamauchi, K. (2003). Eel Biology, Springer, Tokyo.

Anief, M. (2007). Farmasetika, Gadjah Mada University Press, Yogyakarta.

Anonim. (2005). Riset Keanekaragaman Hayati Ikan Perairan Pedalaman di Sulawesi, Laporan Teknis Pusat Riset Perikanan Tangkap, Jakarta. p. 74.

Anonim $^{\mathrm{a}}$ (2010). Sosialisasi Pengelolaan Spesies Endemik Sidat Danau Poso, http://dkp.sulteng.go.id/index.php?opti on=com_content\&task=view\&id=209 \&Itemid $=78$, Diakses pada tanggal 03 Februari 2015, 19.25 WITA.

Gunawan, S.G. (2007). Farmakologi dan Terapi, Edisi Kelima, Departemen Farmakologi Kedokteran UI, Jakarta.

Hairima, Andrie, M., \& Fahrurroji, A. (2014). Uji Aktivitas Salep Obat Luka Fase Air Ekstrak Ikan Toman (Channa micropeltes) pada Tikus Putih Jantan Galur Wistar, Program Studi Farmasi Fakultas Kedokteran, Pontianak.

Mansjoer, A. (2000). Kapita Selekta Kedokteran, Edisi III, Media Aesculapius, Jakarta.

McKinnon, L.J. (2006). A review of eel biolgy : Knowledge and Gaps, EPA Victoria and Audentes Investments Pty, Ltd.

Mercandetti, M. \& Cohen, A. (2014). Wound healing, healing and repair, Emedicine, http://www.eMedicine.com.Inc, Diakses pada tanggal 05 Oktober 2015
Murray, Robert K.G., Daryl K.M., Peter A.R., \& Victor W. 2009. Biokimia Harper, Edisi 27, EGC, Jakarta.

Poedjiadi, A. (2006). Dasar-Dasar Biokimia, UI Press: Jakarta, 115-119.

Price, S.A. \& Wilson, L.M. (1982). Pathophysiology Clinical Conceps of Process, diterjemahkan oleh Peter Anugrah, Patofisiologi Klinik ProsesProses Penyakit, (1995), Edisi ke-4, Buku ke-1, 3-108, Penerbit Buku Kedokteran EGC, Jakarta.

Rovara, O. (2010). Laporan Akhir Alih Teknologi Pemeliharaan Benih Ikan Sidat Teradaptasi Di Kawasan Segara Anakan, Badan Pengkajian Dan Penerapan Teknologi, Jakarta.

Roy, R. (2013). Budi Daya Sidat, Penerbit Agromedia Pustaka, Jakarta

Sinambela. H.Y. (2012). Optimasi Formulasi Sediaan Salep Minyak Ikan Gabus (Channa Striata Bloch) sebagai Obat Luka Sayat dengan Metode Simplex Lattice Design, Skripsi, Program Studi Farmasi, Fakultas Kedokteran Universitas Tanjungpura Pontianak.

Suprayitno. E. (2009). Penggunaan Albumin Ikan Gabus pada Penutupan Luka, Artikel Ilmiah, 1(2) : 1.

Suriadi. (2007). Manajemen Penyembuhan Luka, Stikep Muhammadiyah, Pontianak.

Syamshuhidayat. R. (1998). Buku Ajar Ilmu Bedah Edisi Revisi, Penerbit Buku Kedokteran EGC, Jakarta.

Yazid, E., \& Nursanti, L. (2006). Penuntun Praktikum Biokimia Untuk Mahasiswa Analisis, Andi Yogyakarta, Yogyakarta. 